\title{
ЦИВИЛИЗАЦИОННЫЙ ПОДХОД В ИЗУЧЕНИИ ИСТОРИИ И КУЛЬТУРЫ: ЕВРАЗИЙСКОЕ ВИДЕНИЕ
}

\section{THE CIVILIZATIONAL APPROACH TO THE STUDY OF HISTORY AND CULTURE: EURASIAN VISION \\ D. Kolomyts \\ O. Kolomyts}

Summary: The article is devoted to the consideration of the civilizational approach presented in the Eurasian theory. The methodologies of behaviorism, Freudianism and postmodernism, which were widespread in social science at the end of the XX and the beginning of the XXI century, do not allow us to draw deep conclusions about the ways of social development. The scientific potential is preserved by Marxist and civilizational methodology. In this case, we will talk about the civilizational approach, namely its Eurasian vision. Eurasianism has developed some provisions of the civilizational approach about the selfsufficiency of civilizations, their life as a system of interaction of material and spiritual components.

Keywords: theory of knowledge of civilization, civilizational approach, methodology, Eurasianism, Slavophilism, patterns, historical development.
Коломыц Дмитрий Михайлович

К.полит.н., доцент, Казанский федеральный университет kolomits@list.ru

Коломыц Ольга Григорьевна

К.и.н., дочент, Казанский федеральный университет olgakolomyc793@gmail.com

Аннотация: Статья посвящена рассмотрению цивилизационного подхода в изучении истории и культуры, представленного в евразийской теории. Распространённые в обществознании в конце XX - начале XXI века методологии бихевиоризма, фрейдизма и постмодернизма не позволяют сделать глубокие выводы о путях общественного развития. Научный потенциал сохраняет марксистская и цивилизационная методологии. В данном случае речь пойдёт 0 цивилизационном подходе, а именно 0 его евразийском видении. Евразийство развило некоторые положения цивилизационного подхода 0 самодостаточности цивилизаций, их жизни как системы взаимодействия материальных и духовных составляющих.

Ключевые слова: теория познания цивилизации, цивилизационный подход, методология, евразийство, славянофильство, закономерности, историческое развитие.
$\mathrm{B}$ конце XX, начале XXI века распространены методологии бихевиоризма, фрейдизма и постмодернизма, которые раскрывают частные гуманитарные закономерности. Но попытки расширить области применения этих методологических подходов приводят к глубоко ошибочным выводам. В этой связи, утрачивая научность, данные подходы всё более решают идеологические задачи. Исследование истории постоянно сталкивается с политическим давлением. Результаты научных исследований часто не отвечают целям государственных и политических идеологий. Поэтому по отношению к обществоведческой науке присутствует двойственность. Важнее оказываются политические интересы, которые должны быть поддержаны наукообразными выводами.

Научный потенциал сохраняет марксистская и цивилизационная методологии. В данном случае речь пойдёт о цивилизационном подходе.

Цивилизационный подход основан на положении, что природные условия - климат, наличие рек и морей, лесов и степей, являясь основой общественного хозяйства, влияют на развитие языка, обычаев, религии, и обязательно дополняется историческими условиями жизни народа - наличием соседей, переселением народов и уровнем их развития, выливающиеся в войны, торговлю, ассимиляцию, интеграцию, сосуществование и т.д. В этой связи в развитии обществ материальные и духовные составляющие действуют одновременно.

Методологии изучения истории, культуры и общества включает изучение хозяйственной жизни, природной среды, общественного устройства, политической жизни, мировоззрения (включающие культуру, религию и верования), национально-этнической жизни, международных отношений. Каждому направлению свойственна собственная совокупность методов.

Цивилизационный подход в российской науке можно с достаточной долей условности разделить на социально-географическое направление (П.П. СемёновТянь-Шаньский, Д.И. Менделеев, П.И. Мечников), военно-стратегическое направление (Д.А. Милютин, Н.М.Пржевальский) и евразийство. Создатели этих направлений использовали свою методологию применительно к геополитике. В отличие от двух первых евразийское направление несёт на себе ещё и значительную мифологическую нагрузку, особенно в философии «туранства», представленного Г.В. Вернадским [2, 
3], Н.С. Трубецким [16, 17], П.Н. Савицким [11] и Л.Н. Гумилёвым [6], и идеализации русских духовных традиций. При этом надо понимать, что эта мифология опирается на действительные отличия духовной культуры народов, но не выявляет никаких закономерностей, ни их развития, ни их изучения.

Евразийство как научное направление опиралось на изучение международных отношений, природной среды, хозяйственной жизни, национально-этнических отношений. В данной статье речь пойдёт о цивилизационном подходе евразийского направления.

Наиболее успешным можно считать применение цивилизационного подхода, описывающего и объясняющего те закономерности, которые опускаются при применении марксистской методологии. В России цивилизационный подход зародился как итог диалектического развития движения славянофилов, начало которому положили русские писатели-славянофилы.

Цивилизационный подход направлен на изучение закономерностей взаимодействия природы и духовной жизни, особенностей миропонимания и мировоззрения, их влияния на развитие культуры, а через неё на экономическую и политическую жизнь общества $[7,9,11,18$, 19].

С другой стороны, цивилизационный подход позволяет привлечь к изучению общественных отношений методы исторической науки, этнографии и культурологии. В связи с этим использование формационного универсалистского подхода, определяющего общие закономерности социально-экономического развития, дополненные изучением особенностей исторического развития различных цивилизаций, даёт возможность определять общее, особенное и единичное в общественном развитии, выявлять необходимое, закономерное и случайное (как вмешательство иной закономерности) в историческом процессе.

Развитие цивилизационных подходов затруднялось тем, что их одностороннее применение приводило к жёсткой идеологизации выводов и служило только политическим целям. Особенно это касалось использования этого подхода в геополитике стран империализма, где он превращался в способ идеологического утверждения той или иной концепции (Ратцель, Мэхэн, Хантингтон и пр.).

Согласно цивилизационному подходу, исторические отличия, влияющие и даже определяющие развитие народа, заключаются в особенностях исторического развития, связывающих природные и духовные особенности [7].
Идея отдельности цивилизаций, разрабатывавшаяся евразийцами, сама по себе не нова. Она нашла отражение ещё в теории развития исторических цивилизаций от Древнего Египта до цивилизаций Азии XIX веке. Что касается положения дел в XXI веке, то она отстаивается теми государствами и народами, которые стремятся к политической и духовной независимости, ощущая угрозу собственным устоям и самостоятельности со стороны утверждаемых Атлантической цивилизацией универсалистских концепций развития государств и культур.

Методология евразийцев сочетала в себе несколько подходов. Прежде всего, они касались вопросов, позволяющих найти основания для различения цивилизаций. Относительно внутреннего развития государств большое распространение получила органическая методология государства, в которой оно сравнивалось с живым организмом, функционирующим благодаря наличию внутренних связей между структурами управления и народными слоями так же, как в живом теле эти связи действуют между органами. Начало использования данной методологии положил основатель евразийства Н.Я. Данилевский. Он использовал «органическую теорию» как методологию при создании своей социологической концепции. Согласно органической теории, сущность отдельного тела совпадает с сущностью природы, а планета напоминает организм. Сторонников этой теории было достаточно много (О. Конт, Э. Дюркгейм, Г. Спенсер и др.). Сама органическая методология имеет отношение к философскому осмыслению строения мира. Причины внутреннего развития евразийцы равно видят в материальных условиях и духовных составляющих общественной жизни.

При рассмотрении цивилизационного подхода со стороны евразийцев надо учитывать, что они видели мир через сопоставление и изучение противоречий между Россией и Западным миром. Но выводы, которые они делали, оказались шире собственно предмета изучения, и позволяют использовать евразийскую теорию для геополитики, а методологический подход для изучения всех цивилизаций.

Можно утверждать, что по содержанию евразийство питается всеми соприкасающимися теориями, используя их как обоснование особого пути России, так и направленности дальнейшего развития. В отличие от предшественников, евразийцы обратились к поиску, в том числе и материальных условий, отличающих русскую цивилизацию от всех иных.

М. Раев, осмысливая опыт евразийства, написал, что одним из этих условий, отличия русской цивилизации, была сама история евразийского материка, которая определялась борьбой степи и леса и победой леса, олицетворяемого Русью [10]. По их мнению, наследие 
степей в русской истории заметно, но сущность её раскрывается в христианстве. Большевистская революция также оказалась восстанием Евразии против чуждого влияния. Поэтому культура России в виде противостоящего католицизму православия, так и большевизма, приобрела антизападную направленность. Главное отличие заключено в чуждости Запада духу России. И эта чуждая, отторгаемая культура насильственно навязывалась России Петром Великим [10].

Евразийцы и почвенники утверждали, что Русская цивилизация и Западная разделены на уровне чувств. Это различие переходит на уровень качественных различий в миропонимании. Н.С. Трубецкой писал, что Россию и Запад разделяет "гнев иностранцев на "славянскую душу" и русское "варварство" [10]. Это заключение очевидно сделано на основе наблюдения. Мифотворчество в сознании человека Западного мира начинается с поиска рациональных причин, почему Россия так ему ненавистна. Именно миропонимание окончательно в исторически наблюдаемой перспективе развело цивилизации.

Но, определяясь геополитически, евразийцы видели сосуществование цивилизаций как неизбежность, поэтому предложили начальной точкой всякого исследования считать цивилизации самодостаточными единицами мировой истории. «Славяне не предназначены обновить весь мир,- писал по этому поводу Н.Н. Страхов, - найти для всего человечества решение исторической задачи; они суть только особый культурно-исторический тип, рядом с которым может иметь место существование и развитие других типов» [5].

Отталкиваясь от данного положения, Данилевский указывал, что история славянства даёт пример другого подхода к истории [15]. И. с этой точки зрения, славянофильство защищает самобытность и национальный быт и сознание, особенно в условиях захвата, подчинения и разрушения самосознания со стороны носителей чуждой культуры [5]. Главная опасность состоит в давлении Западного мира на Россию, поэтому российское западничество - «пагубное заблуждение», которое возникло из-за «смешения понятия частной европейской, или германо-романской цивилизации с цивилизациею Общеили, правильнее, Всечеловеческой» [7]. Звучит вполне современно и для XXI века в отношении представлений о Западном мире как всеобщего, при видении других цивилизаций даже не как особенного, а как некоего отклонения от единственного, представляемого, как всеобщее.

Цивилизационная методология опирается на разницу условий жизни народов и поэтому позволяет изучать историю цивилизаций, будучи свободной от общих схем и предопределённостей. В трудах К.Д. Карсавина, Вяч. Иванова, Н. Бердяева, отличие Европы от России со- стоит в совокупности отличий духовной жизни $[9 ; 2 ; 8$; 14]. Вяч. Иванов опирался на философское положение о превосходстве духовной жизни над материальной. «Есть особенности народной психологии, есть черты национального характера и гения, которые надлежит принять как типический феномен и внутренне неизбежный двигатель судеб страны. Как бы мы ни объясняли их - географическими и этнографическими условиями и данными материального исторического процесса или причинами порядка духовного, - мы равно должны признать их наличность, действенность, быть может, провиденциальность в развитии народа» - писал он в своей статье «Русская идея» [8] В данном высказывании философ утверждает, и наличие материального начала в культуре наравне с духовным, и вроде бы, указывает на их равенство, но в дальнейшем своём анализе опирается исключительно на религиозное сознание как основу народной культуры.

Вклад евразийцев в данном вопросе в том, что они свели в систему исторические, географические и культурные составляющие общественной жизни. Можно не соглашаться с некоторыми сделанными ими выводами, но важность такого подхода очевидна. Понятия 'культурно-исторический тип,, 'культурно-историческая единица', используемые первыми евразийцами, говорит о системности их подхода.

Ещё одно методологическое суждение евразийцев утверждает самодостаточность цивилизаций. Их существование не нуждается в подпитке извне. Данилевский видел преимущество и особость России в том, что она «прошла первые формы своего развития в отдалении от возмущающего влияния чуждой западной жизни» [7]. Бестужев-Рюмин считал, что цивилизацию нельзя «привить», и России нельзя «отречься от своей простой жизни» (по Чаадаеву). Европа и Россия, по его мнению, равные культурно-исторические единицы [1]. Этому суждению противостоит Западничество, распространённое среди пишущего слоя. К.И. Бестужев-Рюмин писал в 1888 г., что «русские литераторы (почти без исключений)... отрицают возможности самостоятельной русской или, скорее, всеславянской культуры» [1]. Схожие мысли он находит в работах философа В.С. Соловьёва. Творчество В.С. Соловьёва приобрело широкую известность в российском обществе. Его точку зрения объединяет с почвенничеством отрицательное отношение к духовному состоянию современной ему Европы. Бестужев-Рюмин приводит мысль Соловьёва, что в петровское время Россия от «цельного инстинктивного творчества перешла к сомнениям, поверке, критике», перенятым с Запада, но обращённые к себе, и очень мало к самой Европе. Критика своего, «старого», свойственна, по Бестужеву-Рюмину, обществу (т.е. интеллигенции)», в то время как народ «хранитель непочатых сил» [1]. 
Диалектика развития получается следующая: никто из славянофилов не думал «возвращаться к старине в том виде, в котором она существовала; им нужно было уяснить основные начала; но этого не понимала публика, постоянно смешивающая основное со случайным». Бестужев-Рюмин называет предрассудком господствующее мнение, что «культура только одна, непрерывно развивающаяся», а иные культуры - ступени этого развития, представленные Европой [1]. Таким образом, евразийцы выступили с важным методологическим тезисом о множественности равнозначных культур, отвергающим европейскую исключительность.

Ещё одним важным методологическим положением стало утверждение евразийцев о неразрывности самой духовной культуры. Они были против идущего ещё от первой научной революции стремления к механистическому разделению явлений. Начиная с аристотелевской традиции систематизации, положенной в основу позитивистской науки до декартовского окончательного отделения духовного от материального, продолжая идти путём дробления, европейская мысль стала систематизировать человеческую душу, противопоставляя одну её часть другой. Ярче всего критика такого положения вещей присутствует у В.С. Соловьёва. Его концепция является, прежде всего, религиозной. Но она сближается с евразийством и предоставляет доказательства применимости цивилизационного подхода для изучения культурных различий между народами. Противоположность Запада и Востока у Соловьёва происходят из различия места религии в жизни [13]. Запад, начавшийся с эллинизма, в конечном итоге совершенно отделил веру от познания, создав «чистую философию и чистое ис- кусство» [12.]. На Востоке же религиозная точка зрения «единственно законная при оценке явлений восточной жизни», и такое миросозерцание составляет основу поиска бога и всего восточного познания [12]. Запад «верил и поклонялся человеческому началу» [12]. Он «... обоготворил произвол, т. е. собственную волю человека», но эта воля оказалась «пустою и лишённую всякого нравственного содержания» [12]. Идеал Соловьёва - соединение «вечного и божественного» Востока и «самодеятельность человека (через власть и через свободу)» Запада [12].

Таким образом, можно выделить следующие методологические положения цивилизационного подхода на основе Евразийства:

- самодостаточность цивилизаций;

- цивилизации есть система, которая складывается под влиянием природных условий и исторического взаимодействия с другими народами, влияющих на духовную жизнь;

- духовная жизнь состоит из религий и традиций, оказывающих решающее влияние на цивилизационное миропонимание;

- природные условия и сложившаяся духовная жизнь определяют всю жизнь цивилизации;

- цивилизации борются и сосуществуют друг с другом, и выбор в пользу сосуществования должен быть завоёван силой цивилизации.

Так, Евразийство совместило методологические установки органической теории, теорию географического детерминизма и теорию культурной исключительности цивилизаций, сделав значительный вклад в разработку цивилизационного подхода.

\section{ЛИТЕРАТУРА}

1. Бестужев-Рюмин К.И. Теория культурно-исторических типов. С. 432-462 / Данилевский Н.Я. Россия и Европа. Взгляд на культурные и политические отношения славянского мира к романо-германскому. - Спб.: Изд-во С.- Пет.-го ун-та; «Глаголъ», 1995. - 552 с.

2. Бердяев Н. Русская идея. Основные проблемы русской мысли XIX века и начала XX века. С. 43-271 / Россия и русская философская культура. Философы русского послеоктябрьского зарубежья. - М.: Наука, 1990. - 528 с.

3. Вернадский Г.В. Монголы и Русь. - Пермь: ЛЕАН; М.: Аграф, 2000. - 480 с.

4. Вернадский Г.В. Монгольское иго в русской истории // Евразийский временник. Кн. 5. - Париж, 1927. С. 153 - 164

5. Галактионов А. Органическая теория как методология социологической концепции C. V-XX / Данилевский Н.Я. Россия и Европа. Взгляд на культурные и политические отношения славянского мира к романо-германскому. - СПБ.: Изд-во СПб ун-та; Изд-во «Глаголъ», 1995. - 552 с.

6. Гумилёв, Л.Н. Древняя Русь и Великая степь. - М.: Мысль, 1993. - 782 с.

7. Данилевский Н.Я. Россия и Европа. Взгляд на культурные и политические отношения славянского мира к романо-германскому. - СПБ.: Изд-во СПб ун-та; Изд-во «Глаголъ», 1995. - 552 с.

8. Иванов Вяч. Русская идея. С. 226 - 240 / Русская идея. - М.: Республика, 1992. - 496 с.

9. Карсавин Л.П. Основы политики. С. 174-216 / Россия между Европой и Азией: Евразийский соблазн. - М.: Наука, 1993. - 368 с.

10. Раев М. Россия за рубежом. История культуры русской эмиграции 1919-1939. - М.: Прогресс-Академия, 1994. - 296 с.

11. Савицкий П.Н. Географические и геополитические основы евразийства. С.297-304 / Основы Евразийства. - М.: Арктогея - Центр, 2002. - 800 с.

12. Соловьёв В.С. Великий спор и христианская политика. С. 99 - 167/ Соловьёв В.С. Сочинения в двух томах. Т. 1. - М.: Правда, 1989. - 688 с.

13. Соловьёв В.С. Грехи России. С. 207 - 211/ Соловьёв В.С. Сочинения в двух томах. Т. 1. - М.: Правда, 1989. - 688 с. 
14. Степун С.А. Россия между Европой и Азией // Россия между Европой и Азией: Евразийский соблазн. - М.: Наука, 1993. - 368 с., С. 307 - 327

15. Страхов Н.Н. Жизнь и труды Н.Я. Данилевского. С. XXI-XXXIV / Данилевский Н.Я. Россия и Европа. Взгляд на культурные и политические отношения славянского мира к романо-германскому. - СПБ.: Изд-во СПб ун-та; Изд-во «Глаголъ», 1995. - 552 с.

16. Трубецкой Н.С. Взгляд на русскую историю не с Запада, а с Востока / Основы Евразийства. - М.: Арктогея - Центр, 2002. - 800 с. С. 208 -265

17. Трубецкой Н.С. Мы и другие / Россия между Европой и Азией: Евразийский соблазн. Антология. - М.: Наука, 1993. - 368 с. С. $77-89$.

18. Фёдоров Н. Вопрос о братстве или родстве, о причинах небратского, неродственного, то есть немирного, состояния мира и о средствах к восстановлению родства: записка от неучёных к учёным, духовным и светским, к верующим и неверующим. - М.: АСТ Москва: Хранитель, 2006. - 539 с.

19. Флоровский Г.П. Евразийский соблазн. С. 237 - 265 / Россия между Европой и Азией: Евразийский соблазн. Антология. - М.: Наука, 1993. - 368 с.

(с Коломыц Дмитрий Михайлович (kolomits@list.ru), Коломыц Ольга Григорьевна (olgakolomyc793@gmail.com).

Журнал «Современная наука: актуальные проблемы теории и практики»

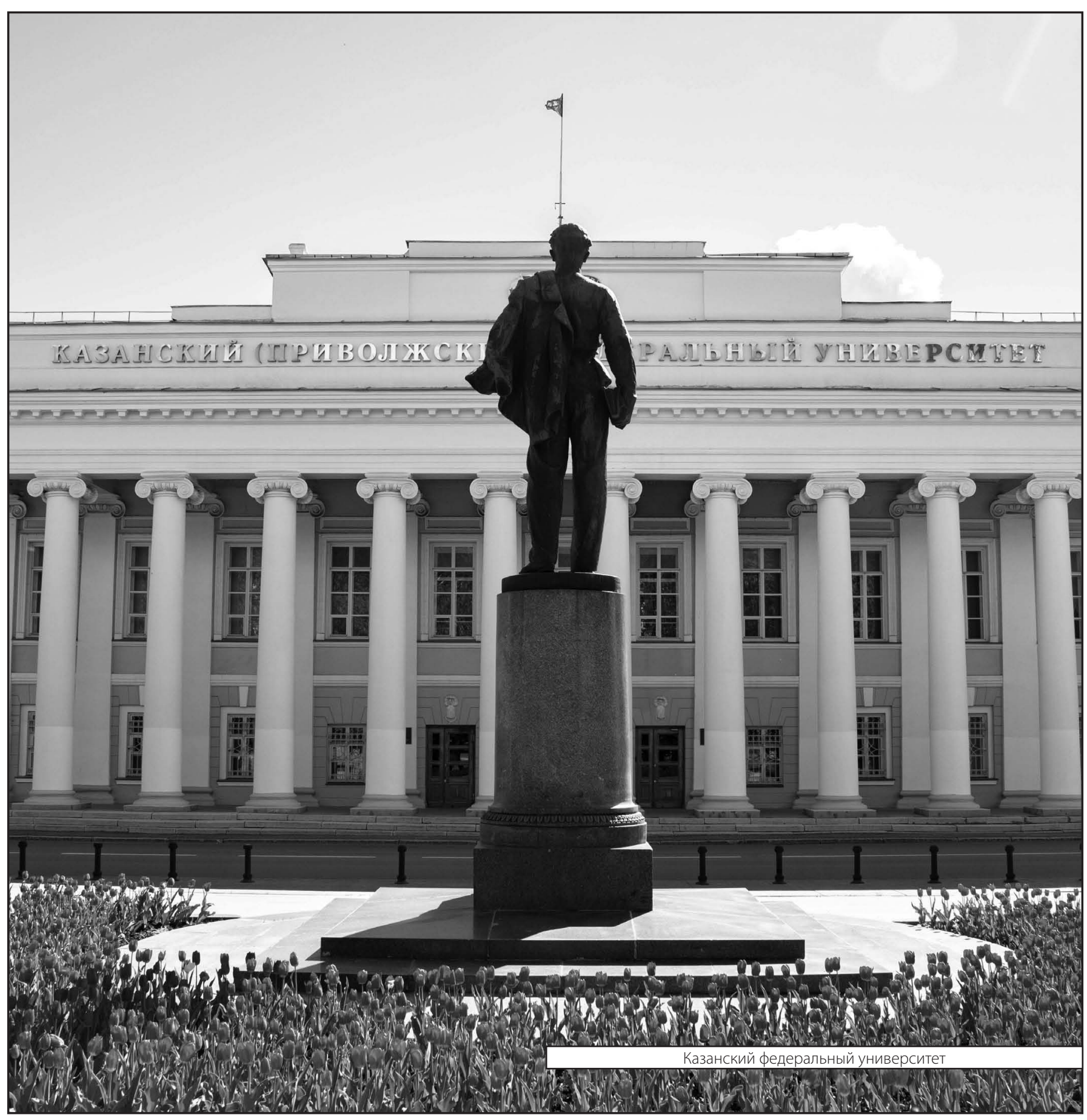

